\title{
Climate change scenarios and potential impacts on water availability in northern Mexico
}

\author{
Víctor Magaña ${ }^{1, *}$, David Zermeño ${ }^{2}$, Carolina Neri ${ }^{1}$ \\ ${ }^{1}$ Instituto de Geografía, Universidad Nacional Autónoma de México, Mexico City 04510, Mexico \\ ${ }^{2}$ RSMAS, University of Miami, Miami, Florida 33149-1098, USA
}

\begin{abstract}
The climate predictability tool (CPT) is often used to statistically downscale the Intergovernmental Panel on Climate Change scenarios presented in the Fourth Assessment Report. The CPT reduces systematic errors and interpolates to a higher spatial resolution grid. Monthly means of surface temperature and precipitation from around 20 climate models for 4 greenhouse gas emission scenarios were downscaled for Mexico. Transfer functions are constructed using the 1900-1970 period and evaluated for the 1971-1999 period, examining the CPT ability to reproduce the observed climatology and trends in temperature and precipitation. The CPT-downscaled ensembles of climate change projections are considered adequate since, after correcting systematic biases in climate models, the observed climatology and trends in temperature and precipitation for the 1971-1999 period compare well with the observed data from the Climate Research Unit at $50 \times 50 \mathrm{~km}$ resolution. The ensemble of downscaled climate change scenarios for the 2000-2099 period is then used to estimate some potential impacts of global warming over Mexico, mostly in water-related sectors. Results show that increases in temperature may be larger in the northwestern than in the northeastern part of the country. Precipitation scenarios project large probabilities of decreases in rainfall over northwestern Mexico, with potential reductions as large as $30 \%$, which correspond to a standard precipitation index of around -1, i.e. a moderate drought. Drought of this magnitude may also bring the vegetation into a state of severe water stress and make it prone to forest fires. The combined effect of increased temperature and precipitation reductions could lead to reduced water availability over northwestern Mexico, especially along the USA-Mexico border region after the 2050s.
\end{abstract}

KEY WORDS: Climate change scenarios $\cdot$ Climate change impacts $\cdot$ Downscaling

Resale or republication not permitted without written consent of the publisher

\section{INTRODUCTION}

Mexican climate ranges from the hot and dry conditions in the northwestern Sonora desert, with an annual rainfall of $<100 \mathrm{~mm}$, to the wet tropical climate in the south, where annual rainfall may reach $>3000 \mathrm{~mm}$. Over most of Mexico, >60\% of the annual precipitation occurs during the boreal summer, i.e. from June through September (García 2003). However, in the northwestern region, the summer rains begin in July, with the onset of the North American monsoon, and end in September (Higgins et al. 2006). Climate variability in arid and semi-arid regions, such as northern Mexico, greatly affects water-related activities. Episodes of precipitation deficit frequently become meteorological droughts, and later may even result in hydrological and agricultural droughts. The impacts of droughts vary from region to region but, in recent decades, they have led to water shortages and conflicts over water allocations along the USA-Mexico border, particularly when the precipitation deficits persist for several years (Endfield \& Fernández-Tejedo 2006), as during the 1950s or the late 1990s (Seager et al. 2009). The 1944 Transboundary Water Treaty between the USA and Mexico requires water deliveries from Mexico to 

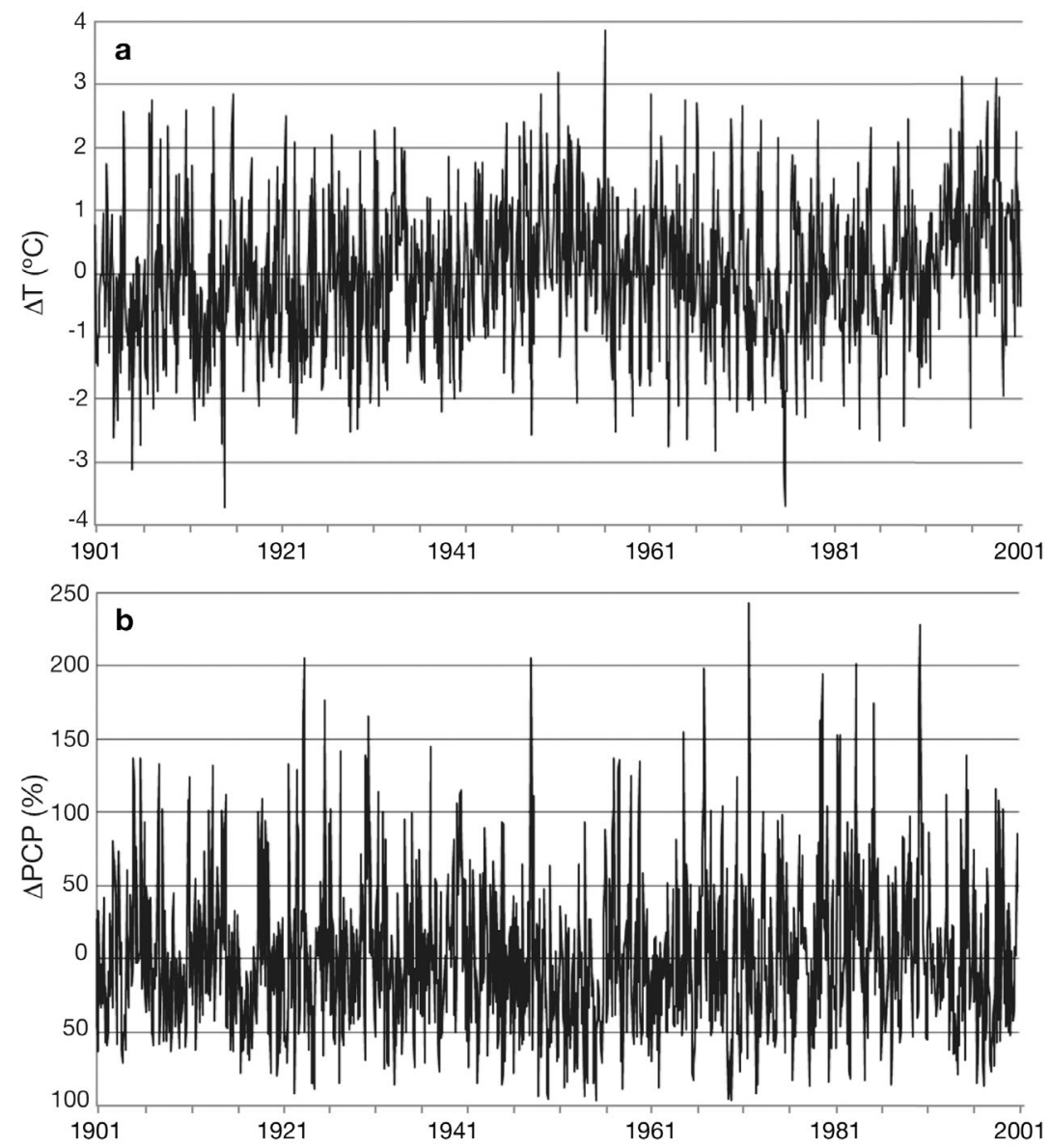

Fig. 1. Monthly anomalies of (a) surface temperature $\left(\mathrm{T},{ }^{\circ} \mathrm{C}\right)$ and (b) precipitation (PCP, \%) over northern Mexico between 1900 and 2002
Current trends in temperature indicate a tendency for warmer temperatures in northern Mexico, of around $+0.8^{\circ} \mathrm{C}$ per 100 yr (Fig. 1a) (Englehart \& Douglas 2003). Precipitation trends are hard to detect considering the large amplitude of interdecadal variations in the hydrologic cycle (Méndez \& Magaña 2010). There is a slight tendency towards a change on the order of $+5 \%$ per 100 yr (Fig. 1b). However, the tendency toward a warmer climate may affect water availability in such a way that prolonged and severe hydrologic droughts may become more frequent (Soule \& Yin 1995). The most severe drought in northern Mexico during the 1950s coincided with the maximum amplitude of warm anomalies. In other words, water scarcity and higher than normal temperature coincide. Such conditions have impelled the Mexican water authorities to consider climate change in their long-term plans (SEMARNAT-INE 2006). This requires a careful consideration of regional climate change projections.

The climate change scenarios in the Intergovernmental Panel on Climate Change Fourth Assessment Report (IPCC AR4, 2007) project that North America, particularly the border area between Mexico and the USA, may be among those regions where more frequent and severe droughts the USA along the Rio Grande, with a minimum amount of $431731000 \mathrm{~m}^{3}$ annually (Sanchez 2006). Between 1998 and 2002, a prolonged and severe drought occurred (Seager et al. 2007), combined with larger water demands in the Conchos basin in Chihuahua, making it difficult for Mexico to meet the water treaty commitments (Sanchez 2006). This prolonged drought episode resulted in a diplomatic conflict (see BBC news online, 28 May 2003: http:// news.bbc.co.uk/2/hi/americas/2940876.stm).

Droughts are part of climate variability. The intensity of a drought depends on both the magnitude of the precipitation deficit and its duration. A meteorological drought results in a soil moisture deficit, which impacts vegetation, wildlife and crops (Wilhite \& Glantz 1985). Droughts end as rains return to normal and soil recovers the necessary levels of moisture to support life. With normal precipitation, lakes, streams and aquifers also recover their normal levels to end hydrologic and agricultural droughts (Adams et al. 1998). may occur (Seager et al. 2009). Considering that the pressure on water resources is extremely high along the USA-Mexico border, climate change constitutes a major threat and risk of crisis for millions of people (Coles et al. 2009). Any adaptation to climate change should take into account projections of climate at the regional level, along with detailed vulnerability assessments by region, sector, or group. In the USAMexico border region, in addition to the uncertainty in any climate change projection, adaptation to climate change in the water sector should consider the binational nature of the hydrologic basins and water reservoirs, as well as the transboundary water treaty.

Climate models have systematic errors that may be present when climate change projections are interpreted at the regional level. In view of our advances in the understanding of low (interannual) (Magaña \& Conde 2003, Magaña et al. 2003) and very low (interdecadal) climate variability (Schubert et al. 2009, Seager et al. 2009, Méndez \& Magaña 2010) in this region, it is now possible to estimate the relative im- 
portance of climate change, particularly over northern Mexico (CICC 2009).

The objective of the present study is to present an ensemble of downscaled versions of the IPCC AR4 climate change scenarios for northern Mexico, correcting some of the systematic errors observed in the atmospheric ocean general circulation models (AOGCMs) in simulations of temperature and precipitation. The climate predictability tool (CPT), used as a statistical downscaling method, allows us to prepare numerous regional climate change projections to estimate the spread among models as a measure of uncertainty in the projected changes of temperature and precipitation. In this way, a range of temperature and precipitation changes may be obtained for the present century and, along with projections of vulnerability, the potential impacts in the water sector estimated.

\section{DATA AND METHODOLOGY}

Climate change scenarios at the regional level provide the information necessary to estimate potential impacts of extreme climate upon the environment and human activities (IPCC 2007). The scenarios should not be viewed as predictions or forecasts, but as internally consistent visualizations of possible future climates, responding to increased radiative forcing. This is particularly important since climate at the regional level is at times affected by elements such as the effects of land use change not included in global models and projections of climate.

The AOGCMs used for IPCC AR4 do not have sufficient spatial resolution to represent some atmospheric processes of relevance for the regional climate of the tropical Americas (e.g. tropical cyclones) or land surface processes that determine the unique regional heterogeneity of the climate of northern Mexico. Until recently, the biases in simulations and the limited number of high spatial and temporal resolution experiments, either with nested models or statistical techniques, affected the confidence concerning regional and local precipitation scenarios and, to a lesser extent, temperature scenarios. Therefore, our approach to the generation of regional scenarios concentrates on reducing systematic errors in various AOGCMs in order to reach an adequate estimate of the expected ranges of change due to increased greenhouse gas concentrations.

Because of the coarse scale at which AOGCMs operate, the geographical locations of coastlines or mountain chains may be distorted, inducing system- atic errors in regional climate simulations. These errors may be propagated in regional climate change scenarios if simple linear interpolation is used as a downscaling tool. Therefore, AOGCMs need to be adjusted so that their output can be interpolated at the regional level. The CPT (IRI 2009) was developed to statistically downscale climate model output from seasonal climate predictions and to perform model validation (Korecha \& Barnston 2007, Moron et al. 2009). The coarse climate model spatial resolution fields of temperature and precipitation (approximately $300 \times 300 \mathrm{~km}$ ) may be downscaled to finer spatial scales on the order of $50 \times 50 \mathrm{~km}$, comparable to observed gridded analyses of regional climate. As in model output statistics (MOS) techniques (Karl et al. 1990), the CPT requires observed and model output data (often called response and explanatory variables) in order to construct transfer functions. Downscaling techniques, such as CPT, calibrate statistical transfer functions through historical relationships between modeled and observed fields so systematic errors in model output are reduced. Identification of such errors is better achieved when not only grid points but also patterns, and particularly variability modes, are correlated (Ebert \& McBride 2000). The CPT scheme is based on pattern comparison by means of either canonical correlation analysis (CCA) or principal components regression (PCR).

Integrations for climate change studies for the IPCC AR4 span from around 1900 to 2100, which makes it possible to construct transfer functions using the high spatial resolution of observed temperature and precipitation fields for the 1900-1970 period. In the present analysis, the stability and skill of the transfer function are evaluated using the 1971-1999 data as an independent sample. As in any bias correction method, the quality of the observational datasets limits the quality of the bias correction. In addition, it is assumed that the bias behavior of the model does not change with time; thus, in the downscaling approach used here, the relationships for the downscaling are supposed stable in a changing climate, i.e. for the 2001-2100 period. This may be a major assumption for any downscaling approach of climate change scenarios (Hagemann et al. 2011).

Various statistical approaches to downscale GCM climate change scenarios for Mexico have been proposed to project the activity of mean, and even extreme, events (Magaña et al. 1997, Cueto et al. 2010). However, most of these are based on a few models only, and lack the benefit of a multi-model 
ensemble perspective, such as the one presented in the IPCC AR4. The AOGCM climate change scenarios used for the IPCC AR4 model projections of surface temperature and precipitation are available at the IPCC Data Distribution Center. Model output fields from around 20 different models for the greenhouse gas emission scenarios A2, A1B, B1 and COMMIT have been CPT downscaled. The 20C3M baseline scenarios for each AOGCM were used as a reference to construct the projected changes in regional climate.

In the downscaling process, the Climate Research Unit (CRU) of the University of East Anglia's monthly temperature and precipitation observed fields, with a spatial resolution of $50 \times 50 \mathrm{~km}$ for the 1901-1999 period, were used (Mitchell et al. 2004). The CRU data capture the very low frequency variability and temporal trends of temperature and precipitation over northern Mexico. For instance, the time series of monthly mean temperature records for La Junta, Chihuahua $\left(28.7^{\circ} \mathrm{N}, 107.9^{\circ} \mathrm{W}\right)$ for the $1936-1984$ period, obtained from the Global Historical Climate Network (GHCN) archive, and the CRU mean monthly temperature data at the nearest grid cell $\left(28.7^{\circ} \mathrm{N}\right.$, $197.7^{\circ} \mathrm{W}$ ) have a correlation coefficient of $\mathrm{r}=0.97$ and an approximate warming tendency of $0.02^{\circ} \mathrm{C}$ per $50 \mathrm{yr}$. For monthly precipitation data, the correlation coefficient between CRU and the La Junta, Chihuahua station is $r=0.88$, and the trend is $+0.75 \mathrm{~mm}$ per $50 \mathrm{yr}$ for La Junta and $0.13 \mathrm{~mm}$ per $50 \mathrm{yr}$ for CRU. It should be noted, however, that the GHCN data used to construct the CRU data base include only ca. 450 stations over Mexico. If these were uniformly distributed over the Mexican territory, a gridded dataset of $70 \times 70 \mathrm{~km}$ could be constructed, close to the grid resolution of the CRU data base.

For the present study, the CPT scheme was used with the PCR method to compare the coarse resolution AOGCM data with the observed high spatial resolution fields and prepare the transfer function. The downscaled fields were constructed with the first 5 modes (EOFs). In this manner, an ensemble of regional climate change projections was prepared for the 2001-2099 period (Table 1).

The capacity to generate monthly fields for a long period makes it possible to reproduce the annual cycle of climatic parameters, as well as the response of the regional climate to large-scale forcing, such as the augmented radiative forcing that results from increased greenhouse gas concentrations. A CPT downscaled realization was incorporated into the ensemble if the 1971-1999 observed trend over Mexico was approximately captured (sign and order
Table 1. Number of IPCC-AR4 downscaled realizations according to the atmospheric ocean general circulation model used for the ensemble

\begin{tabular}{|lcccc|}
\hline \multirow{2}{*}{ Model } & \multicolumn{4}{c|}{ Emission scenario } \\
& A2 & A1B & B1 & COMMIT \\
\hline BCCR_BCM2_0 & 1 & 1 & 1 & 1 \\
CCMA_CGCM3_1 & 5 & 4 & 1 & 4 \\
CCMA_CGCM3_1_T63 & 0 & 1 & 3 & 0 \\
CNRM_CM3 & 1 & 1 & 1 & 1 \\
GFDL_CM2_0 & 1 & 1 & 1 & 1 \\
GFDL_CM2_1 & 1 & 1 & 1 & 1 \\
GISS_MODEL_E_H & 0 & 3 & 0 & 0 \\
GISS_MODEL_E_R & 1 & 2 & 1 & 1 \\
GISS_AOM & 0 & 2 & 2 & 0 \\
INGV_ECHAM4 & 1 & 1 & 0 & 0 \\
INMCM3_0 & 0 & 1 & 0 & 0 \\
IPSL_CM4 & 1 & 1 & 1 & 1 \\
MIROC3_2_HIRES & 0 & 1 & 1 & 0 \\
MIROC3_2_MEDRES & 4 & 2 & 2 & 1 \\
MIUB_ECHO_G & 2 & 2 & 3 & 4 \\
MPI_ECHAM5 & 3 & 2 & 0 & 0 \\
UKMO_HADCM3 & 1 & 1 & 1 & 1 \\
UKMO_HADGEM1 & 1 & 1 & 0 & 0 \\
Downscaled realizations & 23 & 28 & 19 & 16 \\
& & & & \\
\hline
\end{tabular}

of magnitude), and if the downscaled annual cycles of precipitation and temperature for Mexico were approximately reproduced.

We used complementary data for impact analyses. To this end, the normalized difference vegetation index (NDVI) was taken from the NASA data archive (Tucker et al. 2005). This index serves to assess the impact of anomalous climatic conditions on the vegetation and is a measure of the amount and vigor of vegetation on the land surface. NDVI spatial composite images are developed to more easily distinguish green vegetation from bare soils. The index has values ranging from -1.0 to 1.0 , with negative values indicating clouds and water, positive values near zero, indicating bare soil, and higher positive values ranging from sparse vegetation $(0.1-0.5)$ to dense green vegetation ( 0.6 and above). The impact of projected higher temperatures on plants may be estimated considering the large correlation between temperature anomalies and plants over northern Mexico (Ichii et al. 2002). Because NDVI is an indicator of the amount and vigor of vegetation greenness, positive anomalies correspond to healthy vegetation conditions and negative NDVI anomalies to stressed vegetation. Therefore, estimates of changes in soil moisture and NDVI are obtained using CPT as a predicting tool, with surface temperature projections as predictors. 


\section{DOWNSCALING OF PRECIPITATION AND TEMPERATURE}

The CPT is capable of simulating the 1971-1999 climatology for annual mean surface temperature (Fig. 2) and annual accumulated precipitation (Fig. 3). For instance, when the Geophysical Fluid Dynamics Laboratory Atmosphere-Ocean General Circulation Model (GFDL AOGCM) is used, the CPT GFDL downscaled version better approximates the magnitude, shape and location of the main spatial features of the temperature and precipitation fields over Mexico than the coarse model. Similar results were obtained for the rest of the models listed in Table 1.

The CPT version of temperature and precipitation high spatial resolution fields look similar. There are, however, some differences in magnitude, particularly in the precipitation field over central northern Mexico, since the CPT version for the base period (1971-1999), slightly overestimates the annual accumulated precipitation (Fig. 3).

The trend of change in temperature and precipitation are a measure of the sensitivity of climate to increased radiative forcing. The latter has increased in recent years, thus forcing a warmer climate (IPCC 2007). The regional linear trend over northern Mexico for the 1971-1999 period is captured by the CPT regional climate change scenario ensemble. For instance, the CPT-downscaled version of the UKMO_HADCM3 model shows a trend in the mean annual temperature closer to that observed than was the case in the original AOGCM (Fig. 4). This is an important element to consider in the downscaling process.

A similar exercise for the trend in annual precipitation fields shows that the CPT downscaled version of the HADCM3 is closer to that observed than was the case in the original AOGCM (Fig. 5). The magnitude of the tendencies in precipitation, either positive or negative, are exaggerated by the AOGCM but corrected to magnitudes comparable to those observed after applying $\mathrm{CPT}$, as on the Yucatan Peninsula. Some differences between the CPT-downscaled version and the observed fields still exist, but they are much smaller than between the observed trends and the original GCM. For instance, there are regions with a positive trend in precipitation for the 1971-1999 period that appear after applying CPT.

The need to have the largest possible number of realizations in the ensemble has been defined as an important element in probabilistic regional climate change scenarios. For projections for the end of the century, most sources of uncertainty at the global

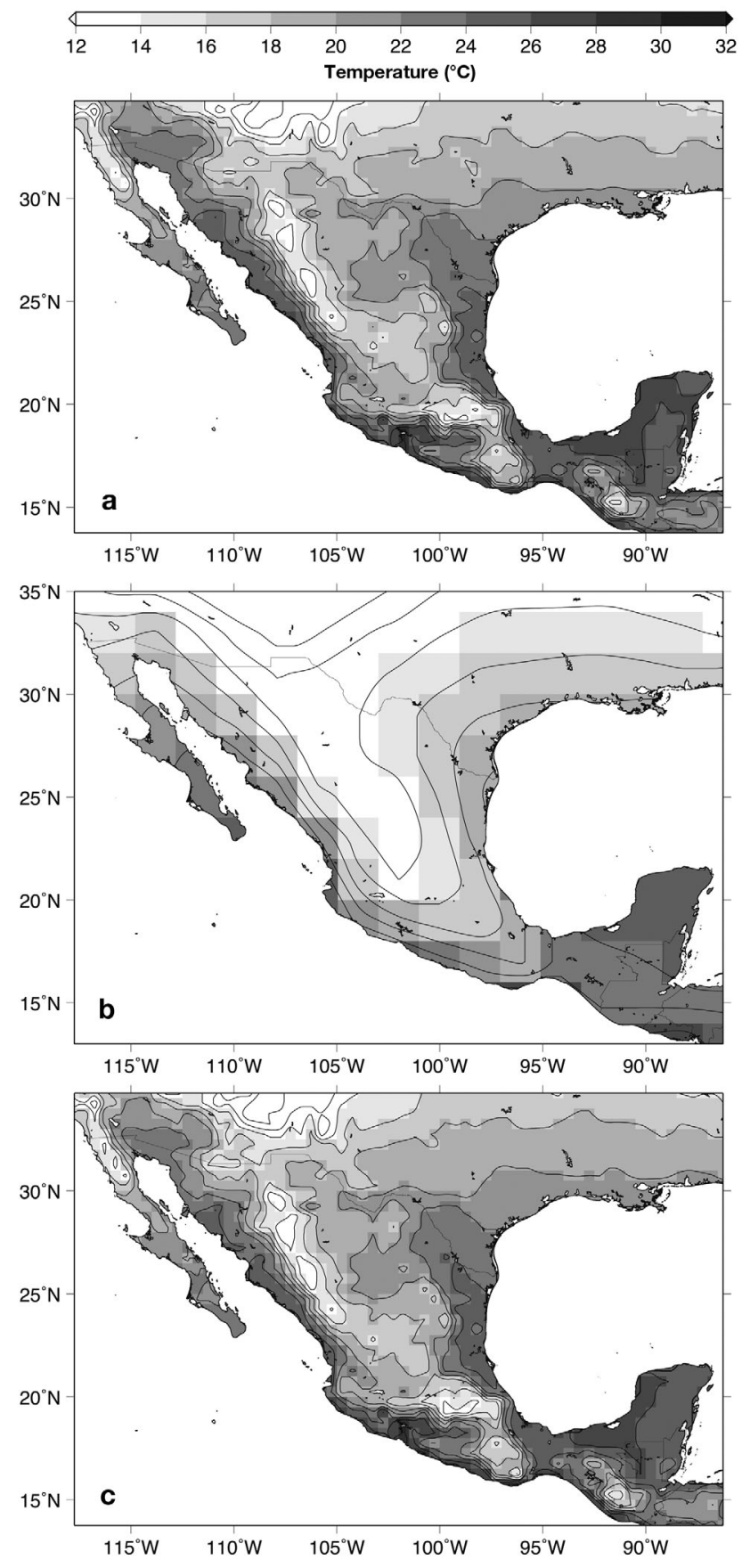

Fig. 2. Annual mean surface temperature $\left({ }^{\circ} \mathrm{C}\right)$ climatology (base period 1971-1999) observed (a) at high spatial resolution with CRU data $(50 \times 50 \mathrm{~km})$, (b) the large-scale GFDL AOGCM $(300 \times 300 \mathrm{~km})$ and (c) CPT-downscaled version of the GFDL AOGCM $(50 \times 50 \mathrm{~km})$

scale have to do with greenhouse gas emission scenarios. However, differences in the projections for the coming decades have to do more with natural variability and the way this is captured in various models (Hawkins \& Sutton 2011), as well as internal 
100200300400500600700800900100011001200130014001500 Precipitation (mm)
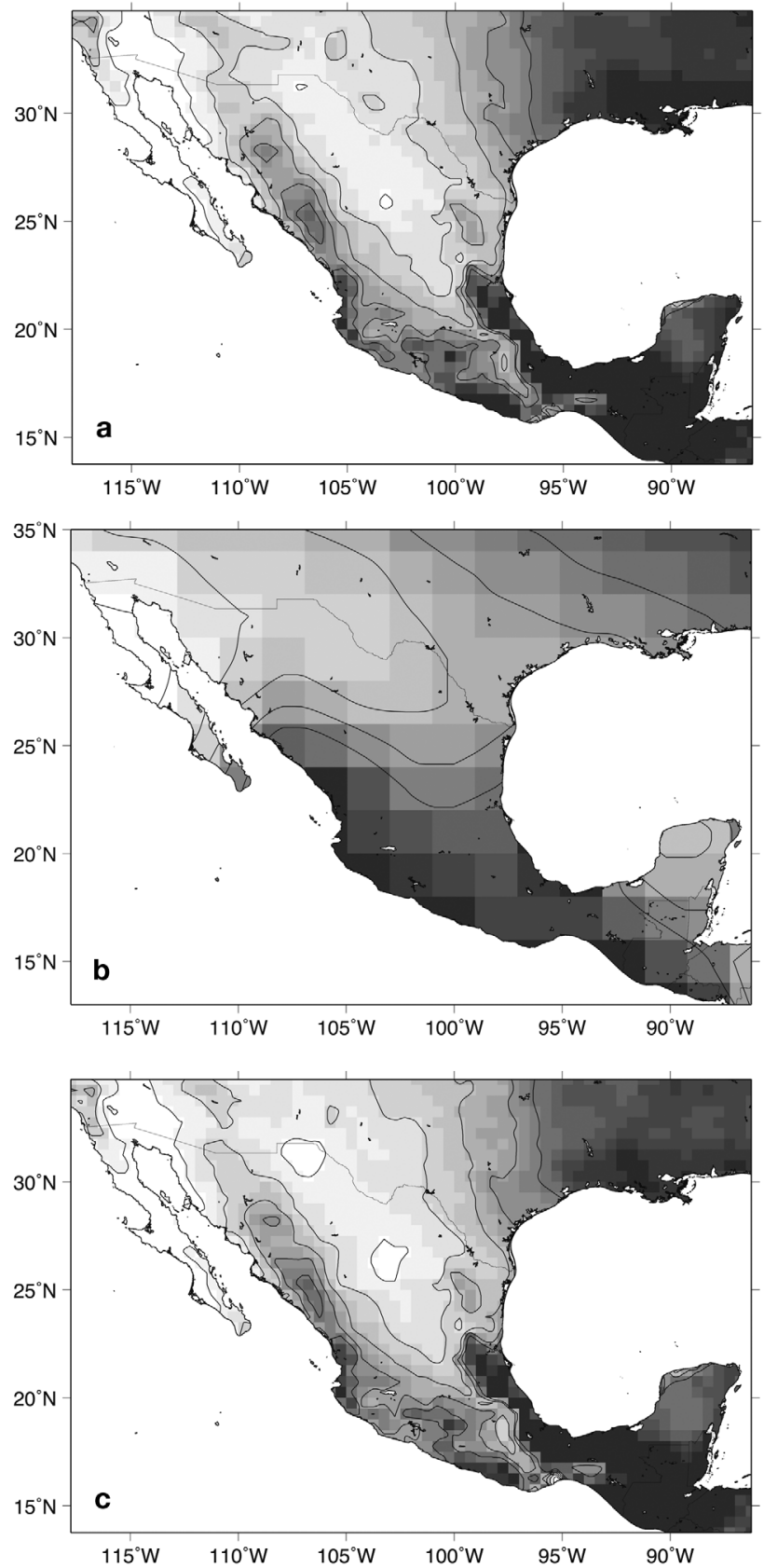

Fig. 3. As in Fig. 2, but for the climatology of annual accumulated precipitation ( $\mathrm{mm}$ ) for the GFDL AOGCM

instabilities or processes not well captured by the coarse spatial resolution of the AOGCM (i.e. tropical cyclones). The differences among climate change experiments has been used as a measure of uncertainty, concluding that the larger the dispersion among models, the larger the uncertainty in the projection. More detailed spatial information also in- creases the uncertainty about the finer scale dynamic processes that result in regional climate. Evaluation of uncertainty at regional and local scales is complicated by the smaller ratio of the signal to the internal variability (Christensen et al. 2001, Hawkins \& Sutton 2011). As in global climate models, regional climate scenarios show there is more consistency among projections of the sign and magnitude of the temperature changes than in the precipitation projections. In any event, the interpretation of regional climate change scenarios requires a certain level of knowledge of the dynamics of processes that result in the characteristic climate of a region.

\section{REGIONAL CLIMATE CHANGE SCENARIOS}

Most studies agree that temperature will increase in the decades to come and that this will affect the hydrological cycle at global and regional scales (i.e. Alcamo et al. 2007). The impacts of permanent changes in climate are expected to have a vast number of socioeconomic consequences, particularly in regions where several natural climatic disasters have occurred in recent decades. The IPCC (2007) has shown that the northern part of Mexico and the southern USA will be among those regions where water deficit will be exacerbated due to the large expected increases in temperature and reduction in precipitation. The downscaled climate change scenarios obtained through CPT are capable of showing the contrasts in projected climatic changes between the regions in northern Mexico. The magnitude of the increase in temperature is expected to vary from the northwest to the northeast, mainly because the dynamic mechanisms that control climate variability are related to processes in the Pacific and Atlantic Oceans (Magaña et al. 2003, Méndez \& Magaña 2010). The mean of the ensemble of downscaled annual surface temperature shows that northwestern Mexico may experience increases on the order of 2.5 $\pm 1.0^{\circ} \mathrm{C}$ by the middle of the 21 st century under the A2 scenario (Fig. 6). Under a medium emission scenario such as A1B (not shown), the increase for the same period in that region is similar to the one observed under A2. It is only after the 2050s that the difference in the projected temperature changes between A2 and A1B become significant (around $1.5^{\circ} \mathrm{C}$ between medians) (Fig. 6).

The increases for the 2070-2099 period are on the order of $3.5^{\circ} \mathrm{C}$ in the northwest and around $3.0^{\circ} \mathrm{C}$ in the northeast of Mexico under the A2 scenario. Under the A1B scenario, the projected increases for 

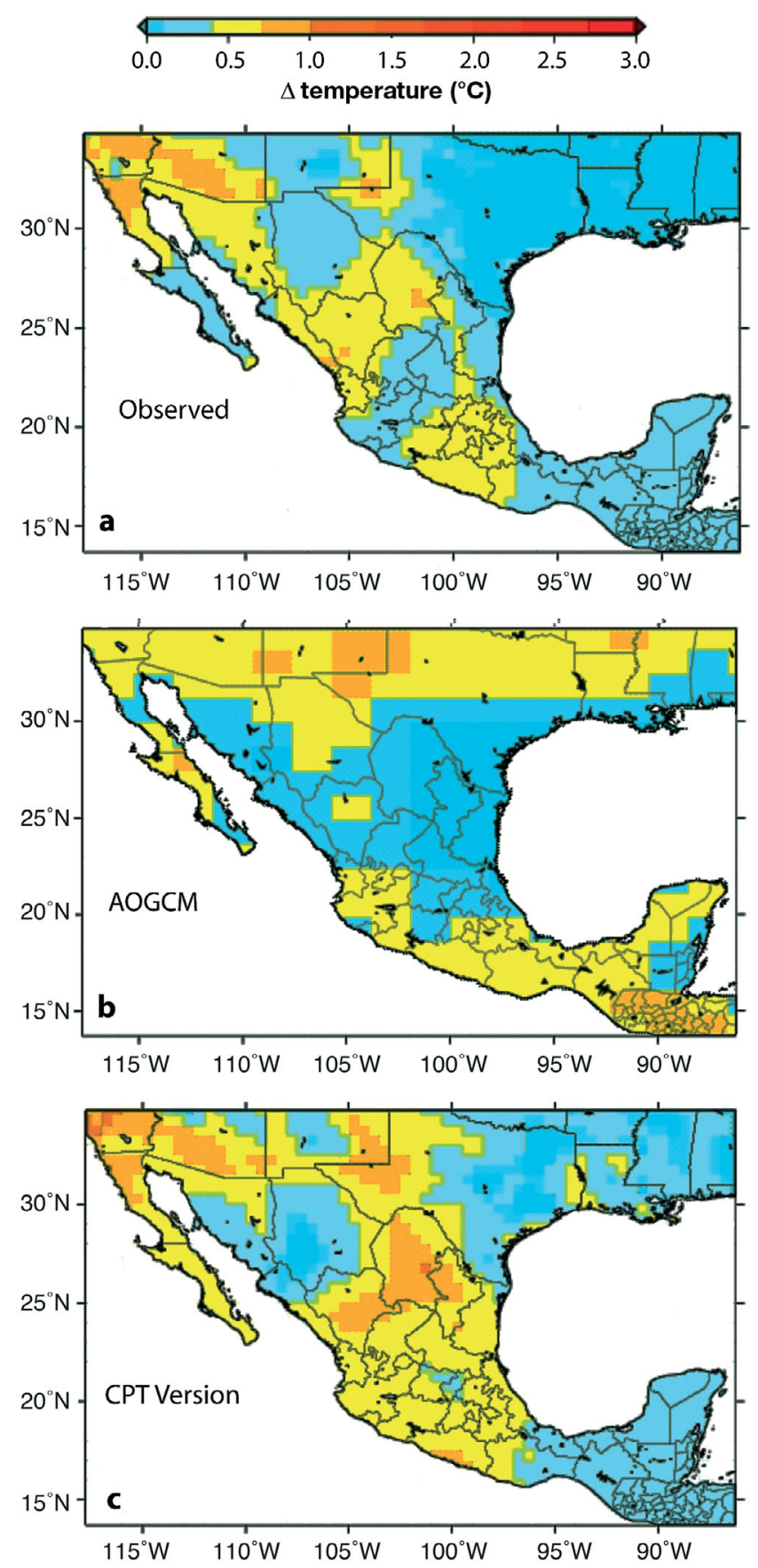

Fig. 4. Linear trends in annual mean surface temperature $\left({ }^{\circ} \mathrm{C}\right.$, between 1971 and 1999) over Mexico (a) observed, (b) HADCM3 AOGCM and (c) CPT-downscaled version of the HADCM3 AOGCM. CPT: climate predictability tool

the end of the present century are around $3.0^{\circ} \mathrm{C}$ in the northwest and about 2.5 in the northeast (Fig. 7). These are the most noticeable regional differences in the projections of surface temperature change in northern Mexico. The Conchos River basin, a key
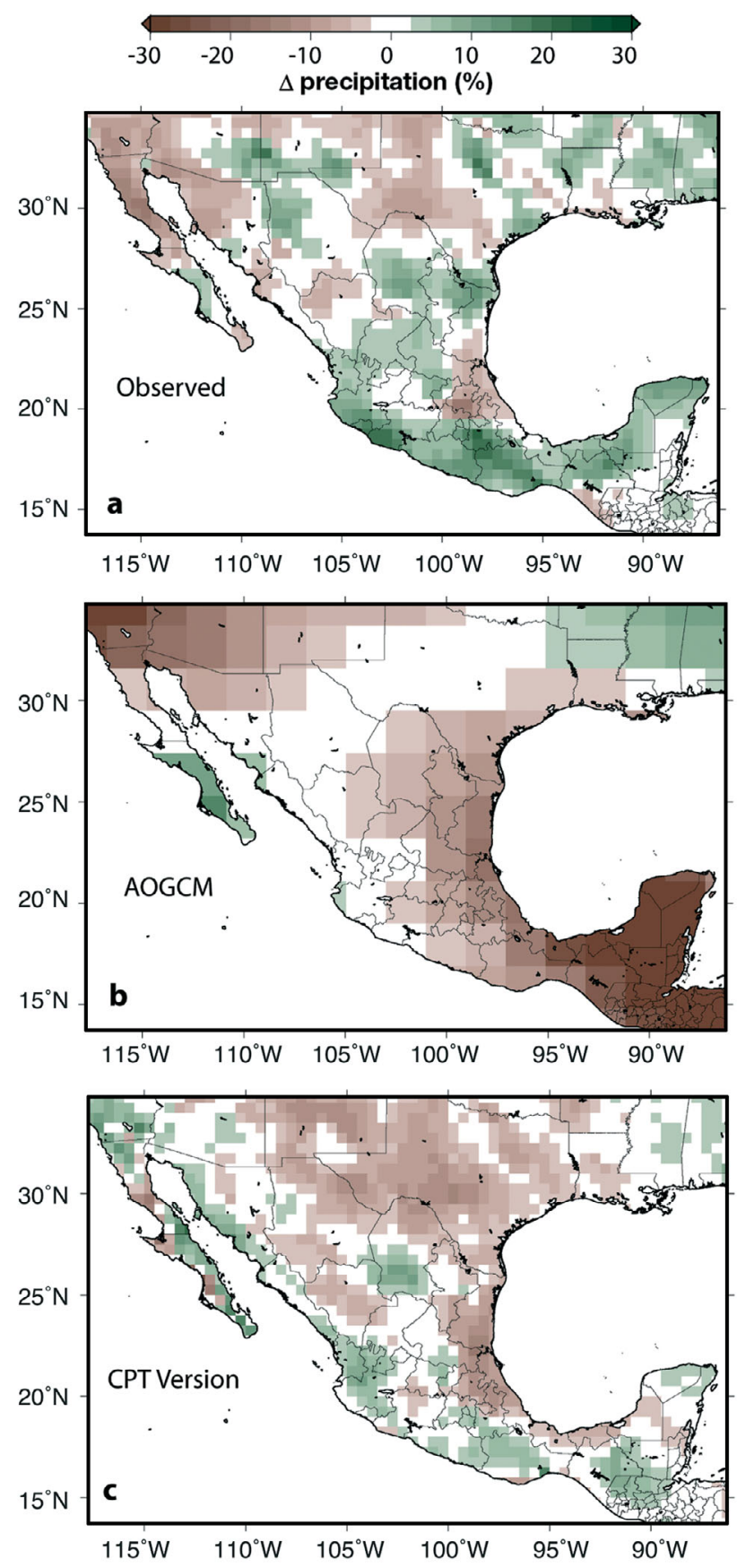

Fig. 5. As in Fig. 4, but for annual accumulated precipitation (\% of change between 1971 and 1999)

region for water transfers from Mexico to the USA under the 1944 treaties, is located in the northwestern part of northern Mexico, where temperature increases are expected to be larger.

In the present analysis, the COMMIT scenario predicts increases of $<1^{\circ} \mathrm{C}$ by the end of the century (Fig. 8) for northwestern Mexico. The A2, A1B and 
B1 scenarios begin to differ from one another after the second half of the 21st century. This difference in projections of temperature beyond mid-century shows the importance of the mitigation of greenhouse gases, since the difference in the magnitude of warming has a significant effect on soil moisture, given the exponential growth of potential evapotranspiration. For some regions of northwestern Mexico, as in northern Sinaloa $\left(105^{\circ} \mathrm{W}, 25^{\circ} \mathrm{N}\right)$ where irrigation fields occur, a scenario of a $3^{\circ} \mathrm{C}$ higher mean temperature and no change in precipitation could reduce soil moisture to zero during the North American Monsoon season, i.e. during June, July and August; at present soil moisture is estimated at around $60 \mathrm{~mm}$. This is an indication of a potential transition to a more arid climate (Seager et al. 2009).

The intermodel range of temperature increase for northern Mexico provides a measure of the uncertainty associated with internal climate variability, parameter uncertainties and the chaotic nature of the climate system. If, for instance, $80 \%$ of realizations around the median are used as the uncertainty range, it may be concluded that warming in northwestern Mexico will be around 1.5 and $3.5^{\circ} \mathrm{C}$ by the mid-21st century (Fig. 9). When outliers are included, warming is up to $5^{\circ} \mathrm{C}$. The increases in the $\mathrm{A} 1 \mathrm{~B}$ scenario are smaller than under $\mathrm{A} 2$, but exceed the $2{ }^{\circ} \mathrm{C}$ threshold considered as critical for several activities such as water management and agriculture (Stern 2006) after the mid-21st century. For instance, in some parts of northwestern Mexico (Sinaloa), a $2{ }^{\circ} \mathrm{C}$ increase in temperature may result in significant maize yield reductions in irrigation fields (OjedaBustamante et al. 2006).

The magnitude and location of the maximum projected changes in temperature, and those projected for northwestern Mexico, tend to match, at these spatial scales, the patterns obtained with dynamical downscaling methods, such as those used in the North America Regional Climate Change Assessment Program (NARCCAP 2009; see www.narccap. ucar.edu/), the Earth Simulator from Japan (PérezPérez et al. 2007) and the PRECIS from the Hadley Center (Campbell et al. 2007). Most CPT and dynamically downscaled projections of temperature tend to produce larger increases of temperature over northwestern Mexico and the Yucatan Peninsula than over the rest of the country. This may be related to the bias of several IPCC AR4 climate models to produce El Niño-like patterns in sea-surface temperature. This is probably the reason for the similarities between CPT and dynamically downscaled temperature scenarios under climate change. For instance, the
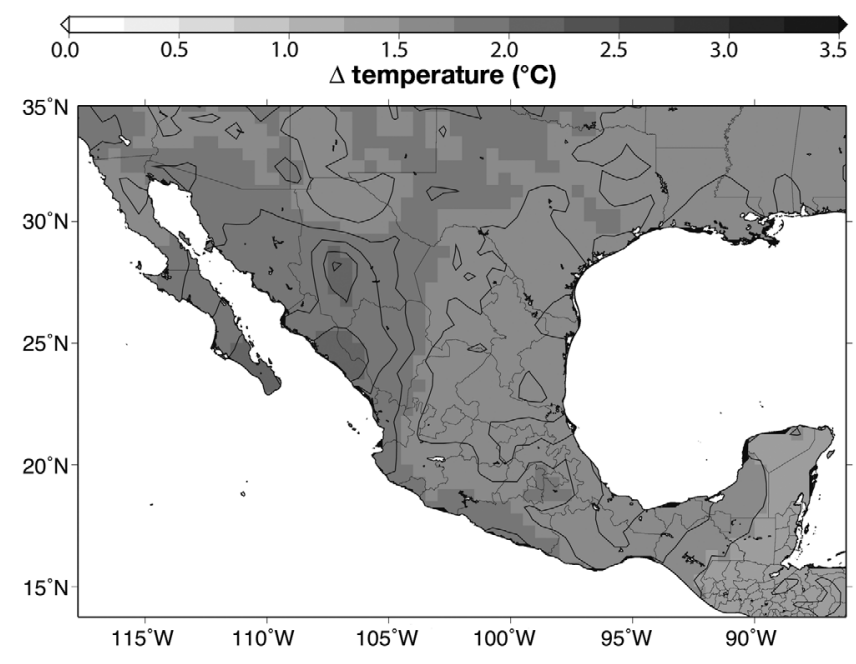

Fig. 6. Median values of the multi-model ensemble of downscaled changes of surface temperature $\left({ }^{\circ} \mathrm{C}\right.$ ) (shading) for the 2040-2069 period with respect to the 1971-1999 climatology under the A2 emission scenario
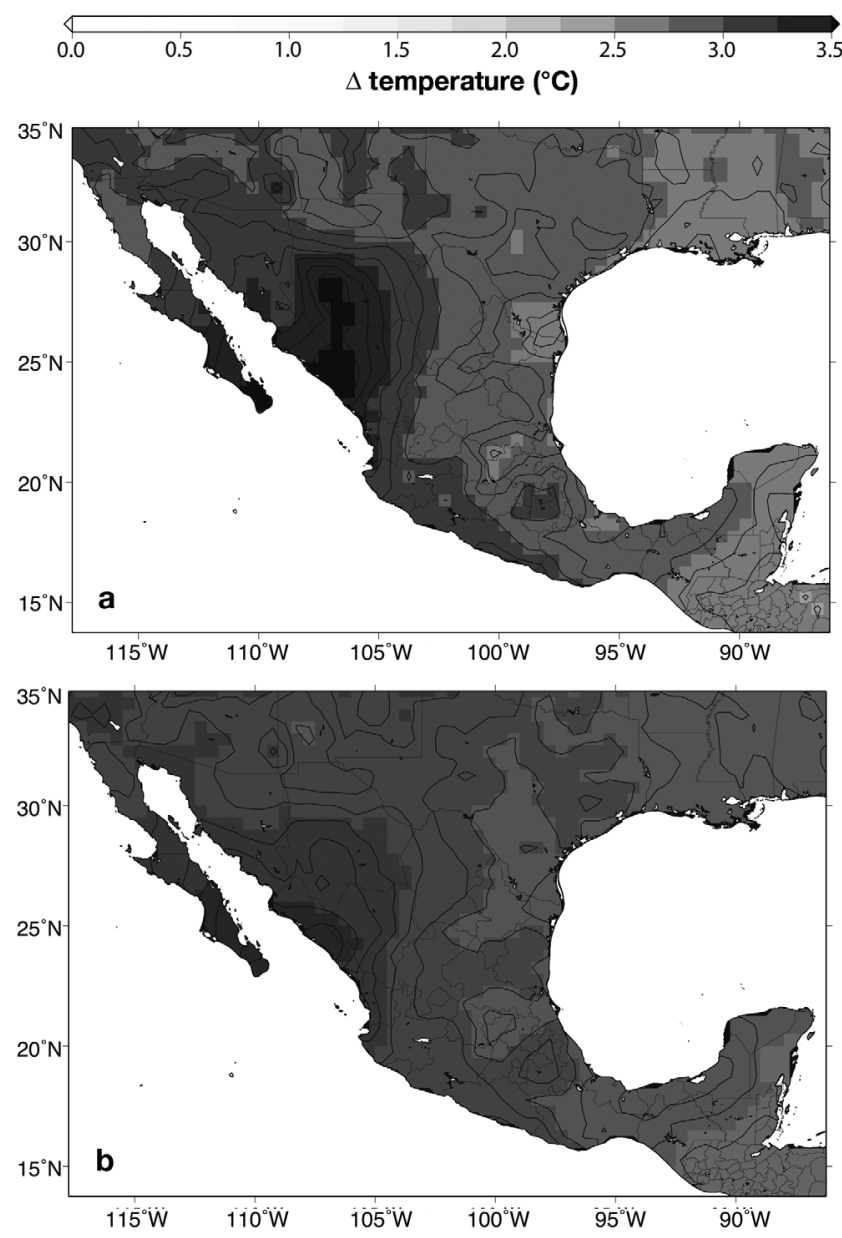

Fig. 7. As in Fig. 6, but for the 2070-2099 period under the (a) A2 and (b) A1B emission scenarios 
Fig. 8. Surface temperature $\left({ }^{\circ} \mathrm{C}\right)$ changes projected for northwestern Mexico and southwestern USA (average $25-33^{\circ} \mathrm{N}$, $117-107^{\circ} \mathrm{W}$ ) for the A2 (solid thick), A1B (dot-dashed), B1 (dashed) and COMMIT (dots) scenarios. The short thick black line corresponds to the observed temperature between 1971 and 1999. The thin grey (solid) lines correspond to the minimum and maximum trends in projected surface temperature among all models. The vertical lines to the right of the plot indicate the range of the ensemble for each emission scenario

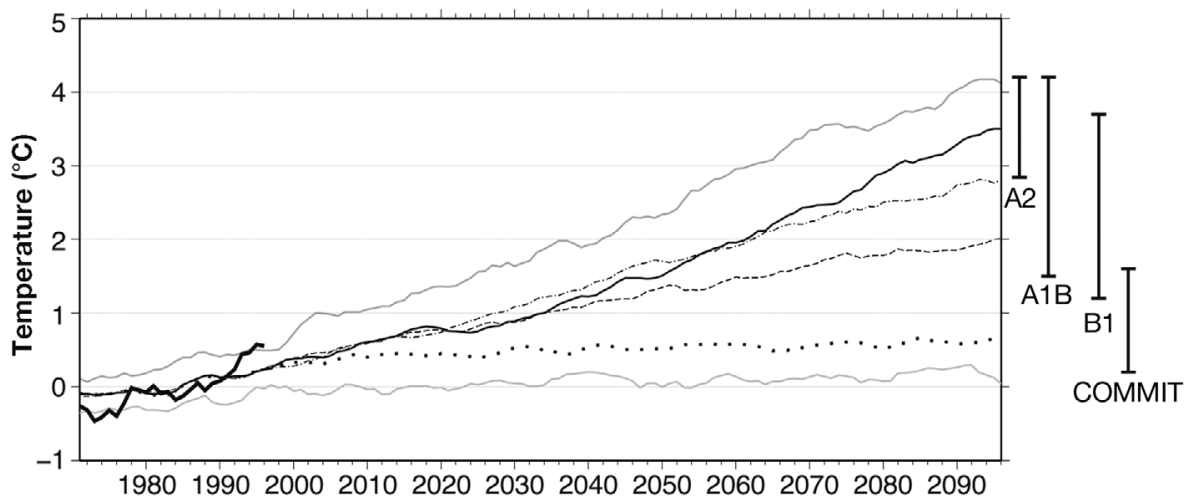

Hadley Centre AOGCM projected an intense warming by the middle of the 21st century over northeastern Mexico, on the order of $3^{\circ} \mathrm{C}$, and a slightly weaker warming over northwestern Mexico, around $2{ }^{\circ} \mathrm{C}$ (Fig. 10a). However, the CPT-downscaled version reduces the magnitude of regional warming distributed over the northern states of Mexico (Fig. 10b). A similar effect is observed in the results obtained by dynamically downscaled experiments for the HADCM3 presented at the NARCCAP site (www.narccap.ucar. edu). Similar results are also obtained for precipitation scenarios. Precipitation projections with the HADCM3 AOGCM tend to produce negative changes to the east and positive changes to the west of Mexico (Fig. 10c). The CPT-downscaled versions of such projections produce positive changes in northeastern Mexico and negative changes in northwestern Mexico (Fig. 10d). Similar results are obtained with the dynamically downscaled version of this model available at the NARCCAP site. This type

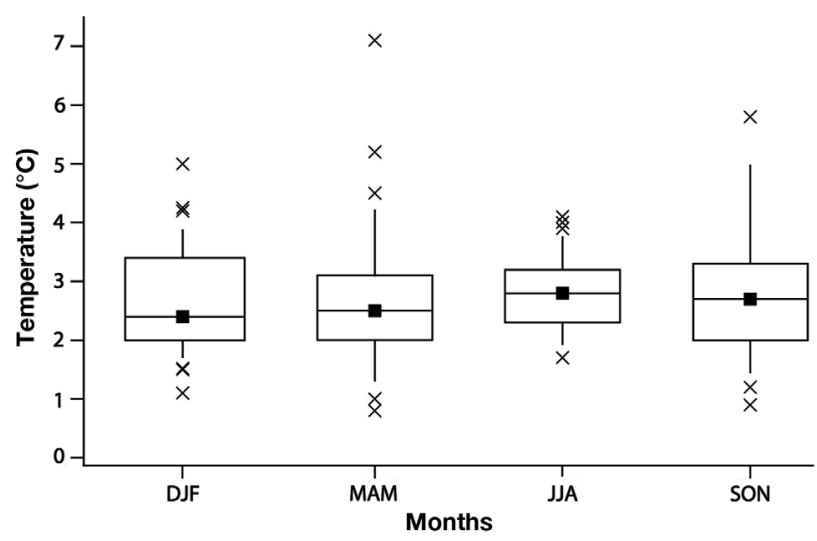

Fig. 9. Boxplots of seasonal projected changes in mean surface temperature $\left({ }^{\circ} \mathrm{C}\right)$ for northwestern Mexico and southwestern USA $\left(25-33^{\circ} \mathrm{N}, 117-107^{\circ} \mathrm{W}\right)$ for the $2070-2099$ period under the A1B emission scenario, based on a multimodel CPT-downscaled scenario. Black squares: median; boxes: interquartile range; whiskers: atypical values; crosses: outliers of result applies not only for the HADCM3 model, but for other models used for NARCCAP.

Mexico is one of the regions of the world where precipitation is more likely to decrease under climate change (IPCC 2007). The downscaled scenarios of changes in precipitation for the 2040-2069 period show that decreases in annual rainfall may occur over most of Mexico (10-20\%), under both A2 (Fig. 11a) and A1B (Fig. 11b). Only in parts of the northeast is there an indication of a small negative or even positive change $(5 \%)$. The projected reductions in precipitation for the states of Sonora, Baja California and parts of Chihuahua may be between 10 and $25 \%$ for the 2070-2099 period (Fig. 11). These reductions in precipitation combined with large increases in temperature imply a large increase in potential evapotranspiration and a substantial reduction in water availability and soil moisture, affecting the irrigation districts of northwestern Mexico. On the other hand, for the northeastern region, in states such as Tamaulipas, the expected magnitude of the negative changes in precipitation is only between -5 and $-10 \%$. Natural climate variability produces larger changes in annual precipitation than those expected under climate change. However, if a large negative anomaly in precipitation resulting from natural variability combined with the negative tendency in precipitation, the negative effect would be magnified.

There is a wide variety of precipitation scenarios among models. The majority of downscaled scenarios indicate that most of Mexico will experience reductions in precipitation. However, there are a few models that project increases in precipitation in these regions (Fig. 12). The magnitude of the projected precipitation change is smaller than the dispersion among models. This makes precipitation scenarios for the present century more uncertain than those for temperature. An additional and important source of uncertainty is the fact that water availability depends on the passage of a tropical cyclone over the region. 

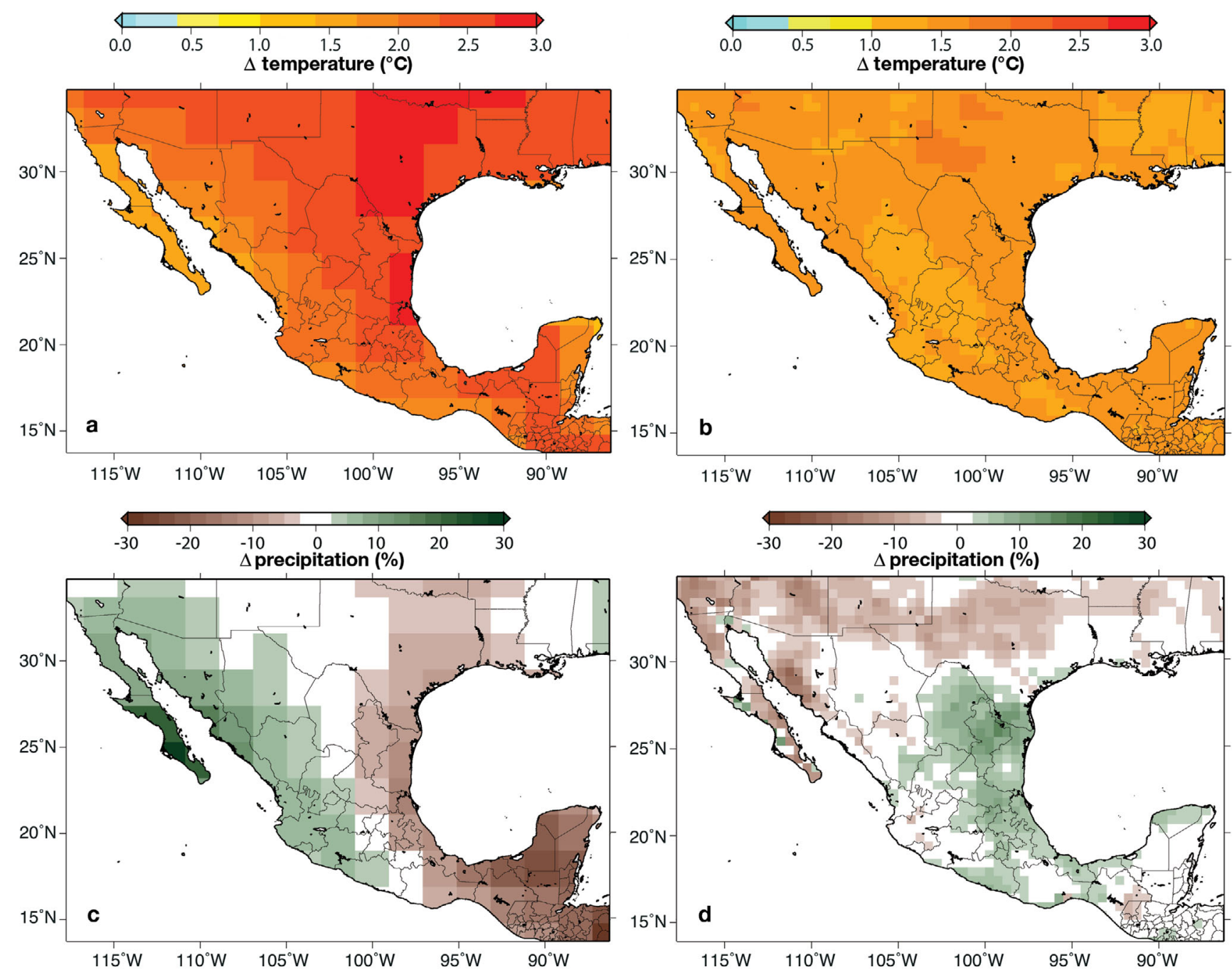

Fig. 10. Climate change projections for the HADCM3 for the 2040-2069 period under the A2 emission scenarios (a) AOGCM for annual surface temperature $\left({ }^{\circ} \mathrm{C}\right)$ change, (b) CPT-downscaled version for annual surface temperature change $\left({ }^{\circ} \mathrm{C}\right)$, $(\mathrm{C})$ AOGCM for precipitation change (\%), and (d) CPT-downscaled version for precipitation change (\%) (see Section '4' for details)

This is a difficult element to incorporate in the regional scenarios. The median of the downscaled scenarios indicates that reductions in precipitation across the USA-Mexico border may be, on average, $<5 \%$ under the A1B scenario during the dry season, and between 5 and $15 \%$ during the wet season. Projected changes under the A2 scenario are similar. Although rains in Mexico during the boreal winter months are meager, they may be important to maintain certain levels of soil moisture and to reduce the water stress in the vegetation during spring (Magaña $\&$ Conde 2003).

The time evolution of the projections indicates that it is more probable that the decreases in precipitation will be important during the second half of the 21st century, i.e. they will show, at least for the A2 scenario a clear negative trend, as observed in the 24 mo Stan- dard Precipitation Index (SPI-24) time series obtained from the CPT-downscaled scenarios. The SPI is a normalized version of the precipitation anomalies and has been used to characterize the severity of meteorological drought (Méndez \& Magaña 2010). The SPI-24 makes it possible to remove the effects of year-to-year variability and reflects the effects of persistent precipitation anomalies. Time series of observed (19011999) and downscaled projections of SPI-24 along the USA-Mexico border region, serve to estimate the potential tendency for more meteorological droughts. The observed SPI-24 time series show the prolonged droughts during the 1910s, 1930s, 1950s and late 1990s in northern Mexico (Fig. 13). The magnitude of SPI-24 during the 20th century was close to -2 when prolonged droughts occurred, which corresponds to the category for extremely dry conditions occurring 


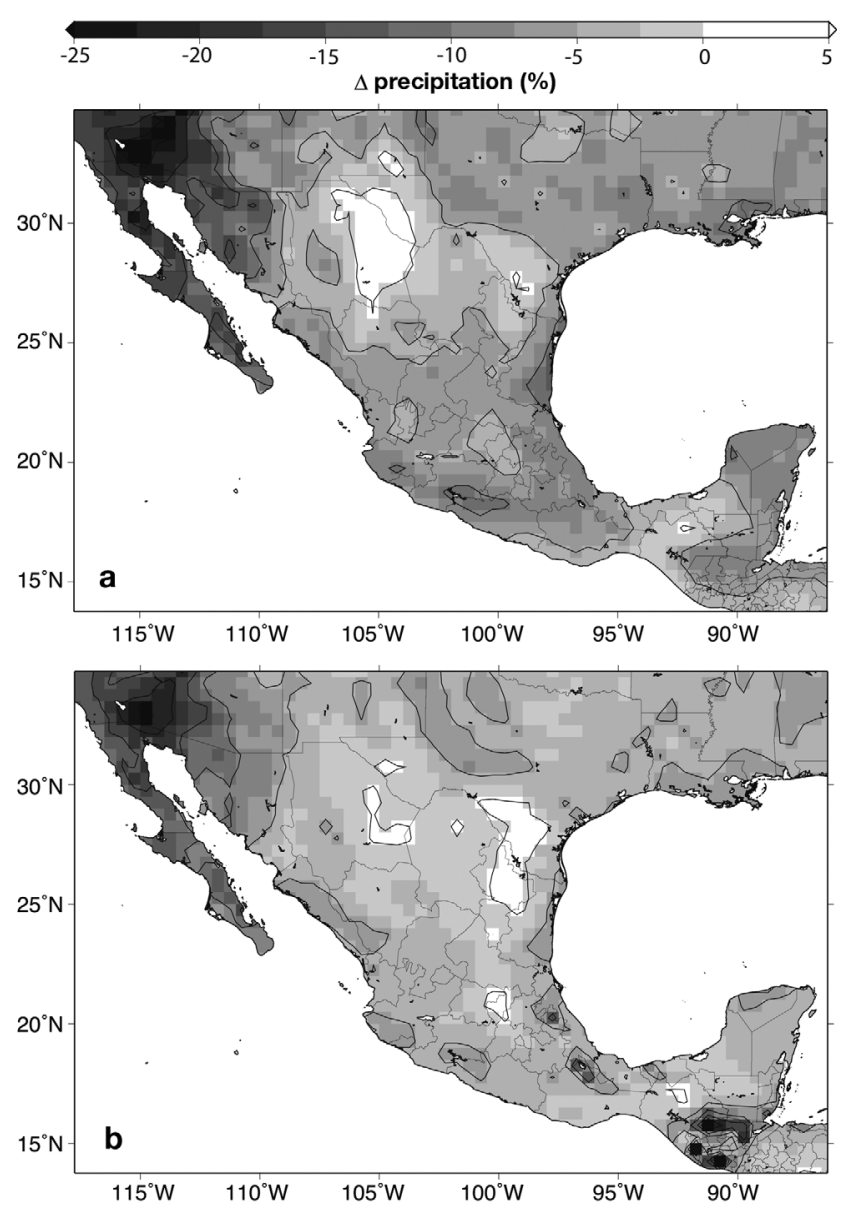

Fig. 11. Projections of changes in annual accumulated precipitation (\%), for the 2040-2069 periods under the (a) A2 and (b) A1B emission scenarios

about $2 \%$ of the time (Méndez \& Magaña 2010). The projections corresponding to the downscaled multimodel ensemble median of precipitation for 20002099 do not have the magnitude of the observed natural variability. However, a more definite trend toward negative values of SPI-24 is observed under the A2 (Fig. 13a) than under the A1B scenario (Fig. 13b), particularly after the 2050s, with SPI-24 values averaging around -1 . Such conditions may be interpreted as semi-permanent moderate meteorological drought over northern Mexico.

\section{POTENTIAL IMPACTS OF CLIMATE CHANGE}

During the 1998-2002 period, droughts were observed in several regions of the northern hemisphere (Zeng et al. 2005), with severe impacts in various ecosystems. During the drought of the late 1990s in northern Mexico, the average level of the Amis-

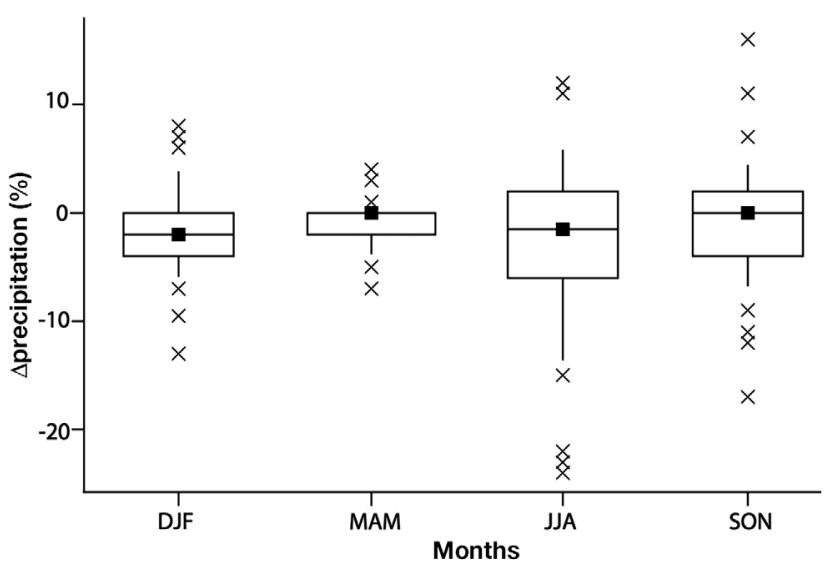

Fig. 12. Boxplots of seasonal precipitation changes (\%) between northwestern Mexico and southwestern USA $\left(25-33^{\circ} \mathrm{N}, 117-107^{\circ} \mathrm{W}\right)$ for the $2070-2099$ period under the A1B emission scenario, based on a multi-model CPTdownscaled scenario. Definitions in Fig. 9

tad-Falcon dam, on the USA-Mexico border, was only $30 \%$ of its total capacity, limiting the capability of Mexico to fulfill the transfer of water from the Conchos basin, from Chihuahua to the state of Texas. The regional climate change scenarios suggest that by the end of the 21st century, water availability in northwestern Mexico may be reduced by up to $30 \%$ because of global warming, due to potential reductions in precipitation and because of the increase in temperature.

Historically, droughts have had serious consequences in important sectors of northern Mexico, such as agriculture, forestry and the environment (Mearus et al. 2009). In order to examine the impact of climate change, the conditions during a similar anomalous warm and dry period may be analyzed. Anomalously high temperatures in northern Mexico persisted during the summers of 1998-2002 (around $+2{ }^{\circ} \mathrm{C}$ ) with precipitation below normal ( -20 to $-30 \%$ ), leading to a prolonged drought. Such climatic anomalies resulted in a severe soil moisture deficit and water stress in crops and vegetation that increased the potential of forest fires. In fact, the spring of 1998 resulted in the season with the largest number of forest fires in Mexico in recent decades, not only due to the hydrologic stress in vegetation, but also to practices of slash and burn in the agricultural sector (Magaña 1999). Vulnerability in northern Mexico has not been reduced since then (Liverman 2001), and, consequently, the risk of a major environmental disaster is still present (Wilder et al. 2010).

The CPT tool was used to project changes in soil moisture (Fig. 14a) and NDVI (Fig. 14b) using temperature as the predictor. The calibrating period for 


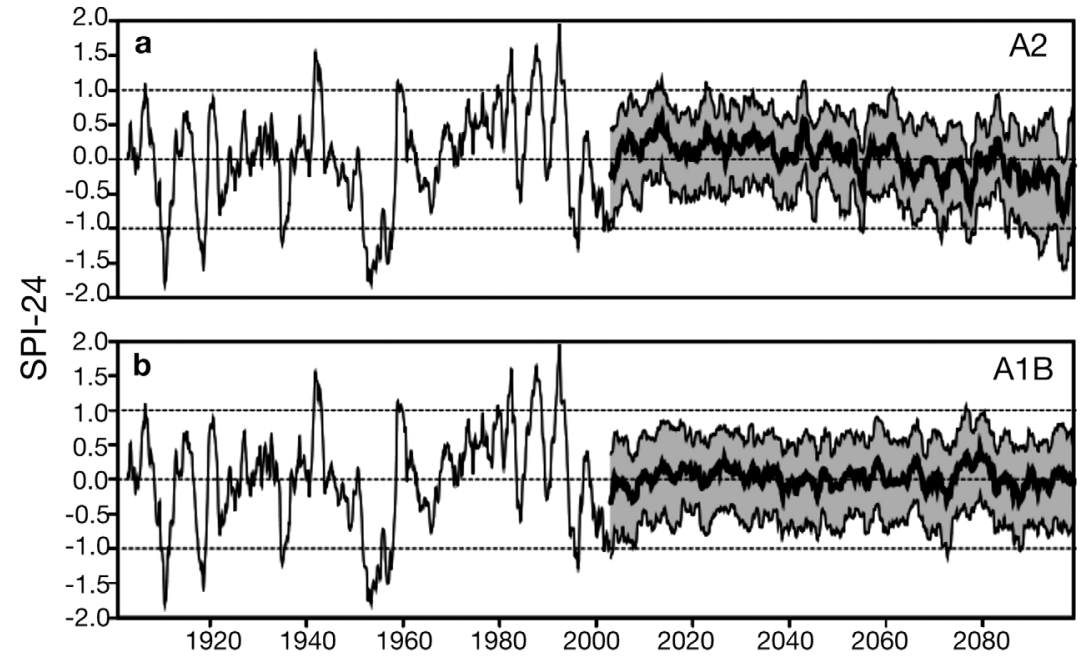

Fig. 13. Time series of the 24 mo Standard Precipitation Index (SPI-24) for the 1900-2000 period (using observed historical data, 1901-1999) and for the 2001-2100 period (using ensemble mean of downscaled precipitation projections, 2000-2099) under the (a) A2 and (b) A1B emission scenarios. Thick black line: median; gray: range of projections this variable is limited to 20 yr (1981-2000), but the close relationship between temperature and soil moisture and NDVI, particularly over northern Mexico (Ichii et al. 2002), allows the development of a transfer function. The NDVI negative changes over northern Mexico are also related, to a lesser extent, to the reductions in precipitation. The projected patterns for the second half of the 21st century correspond to a severe soil moisture deficit and water stress in plants. The projected situation may be examined in the context of previous droughts. For instance, the projected changes in soil moisture and NDVI under the A2 scenario resemble the observed anomalies under El Niño 1997/1998 conditions, particularly over northeastern Mexico (Magaña et al. 2003). Most of the affected regions correspond to semi-arid areas, where natural vegetation is a niche for very rich biodiversity. During March and April 2011, very low-frequency climate variability over northeastern Mexico led to positive surface temperature anomalies close to $5^{\circ} \mathrm{C}$, and considerable water stress in the vegetation. This resulted in a record number of forest fires in the state of Coahuila, south of Texas. Under climate change, this situation would last for several decades.

\section{CONCLUSIONS}

The present study shows that the CPT is a useful method to obtain regional climate change scenarios, since it is capable of reducing systematic errors of the coarse spatial resolution AOGCMs and interpolate to finer spatial scales by means of EOFs. Climate change scenarios show that it is more probable that northwestern Mexico will experience larger in- creases in temperature and reductions in precipitation than the rest of the country. The Conchos basin is in this part of northern Mexico, and the streamflow and surface water may be more severely affected by the larger expected increases in temperature, generating difficulties for Mexico to meet the water treaties with the USA, as in the 1990s.

Such climatic changes increase the possibility of prolonged droughts in the long term, with severe negative impacts on the socio-economic life of northern Mexico. The USA-Mexico border region will have to go through a process of adaptation to climate change to reduce the growing demands for water and ensure more careful management of natural ecosystems, since drier conditions are also likely to affect the vegetation.

To diminish the risks of hydrologic drought, it is necessary to increase the efficiency in water use in the agricultural, industrial and public sectors (Eakin et al. 2007). Climate change scenarios may help with the consideration and implementation of adaptation policies. Prolonged droughts could again cause desperate conditions in the water sector, which are best counteracted by knowledge and cooperation. Several projections of water availability for Mexico during the 2020-2030 period suggest that northern Mexico may be a region where the risk of large deficits in water availability will be high, particularly over the states of Sonora, Chihuahua and Baja California (SEMARNAT-INE 2006). The demands for water will be higher according to some projections (CONAGUA $2011 \mathrm{a}, \mathrm{b})$. If climate change is taken into account, the water problem may become a serious issue in the coming decades (Garfin et al. 2007, Wilder et al. 2010), according to climate change scenarios, such as those presented in this study. 


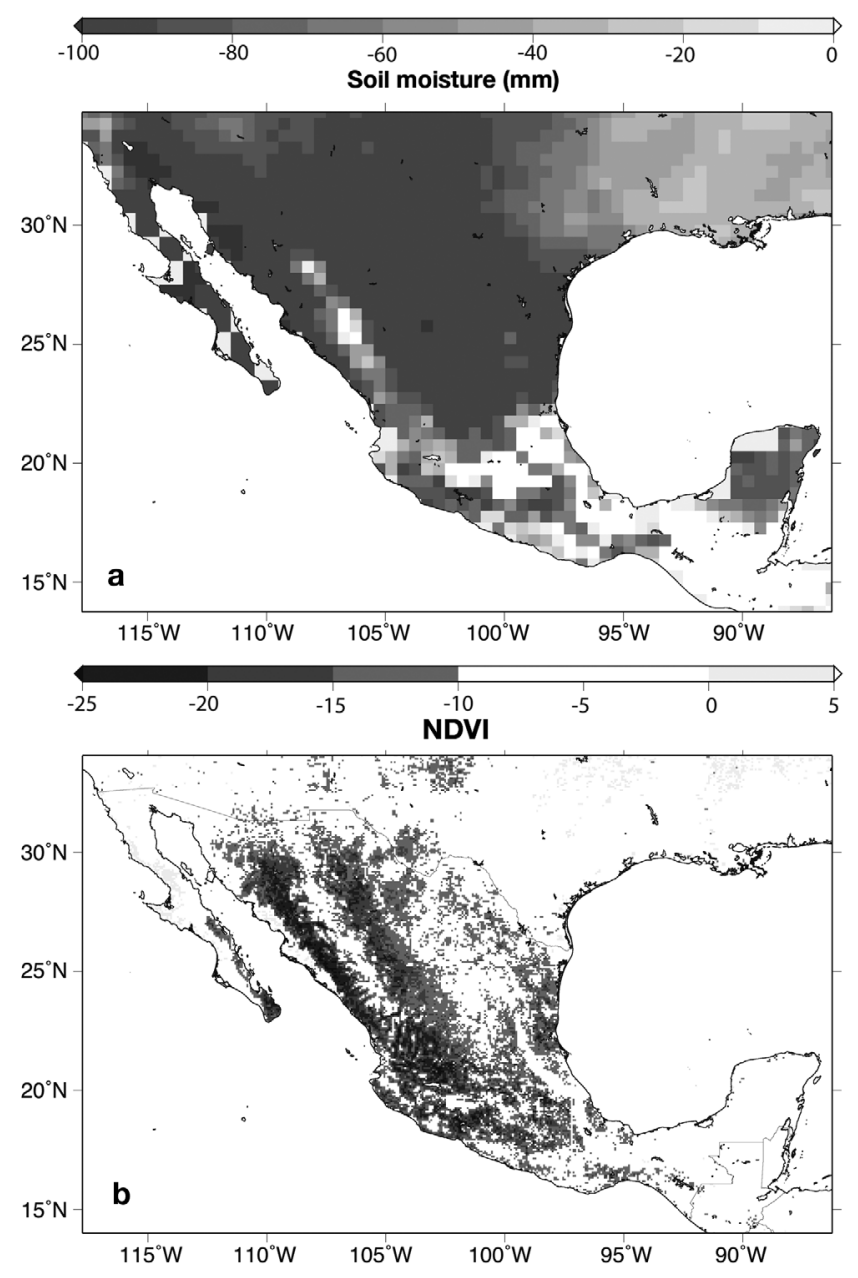

Fig. 14. (a) Soil moisture (mm) and (b) normalized difference vegetation index (NDVI) changes under the A2 emission scenario for the second half of the 21 st century

Acknowledgements. We are indebted to Matías Méndez for useful advice and discussion on the use of SPI and for the preparation of some plots. We thank Gustavo Vázquez for his technical assistance in preparing data files. We also thank the Climate Hydrology Academic Network for Governance and the Environment (CHANGE) for valuable discussions on the subject of transboundary water resources. This work was supported in part by the Consejo Nacional de Ciencia y Tecnología and SEMARNAT under a CONACYTSEMARNAT 2009 Grant, and by the Instituto Nacional de Ecología (Mexico). C.N. and D.Z. were financially supported by CONACYT under the Graduate Scholarship Program. We thank Andrea Ray for valuable scientific comments.

\section{LITERATURE CITED}

Adams RM, Hurd BH, Lenhart S, Leary N (1998) Effects of global climate change on agriculture: an interpretative review. Clim Res 11:19-30

Alcamo J, Flörke M, Märker M (2007) Future long-term changes in global water resources driven by socioeconomic and climatic changes. Hydrol Sci J 52:247-275
Campbell JD, Taylor MA, Stephenson TS, Whyte FS (2007) Generating future climate scenarios for the Caribbean using PRECIS. In: Proc Am Geophys Union, Fall Meeting 2007. (Abstract GC22A-05) Available at: http://adsabs. harvard.edu/abs/2007AGUSMGC22A..05C

Christensen J, Hulme M, Von Storch H, Whetton P and others (2001) Regional climate information-Evaluation and projections. In: Climate Change 2001: the physical science basis. Contribution of Working Group I to the 3rd assessment report of the Intergovernmental Panel on Climate Change. IPCC, Cambridge

CICC (Comisión Intersecretarial de Cambio Climático) (2009) Programa Especial de Cambio Climático 2009-2012. Diario Oficial de la Federación, Tomo DCLXXI, Número 21. CICC, Mexico

Coles AR, Scott CA, Garfin GM (2009) Weather, climate, and water: an assessment of risk, vulnerability, and communication on the United States-Mexico border. In: Proc 89th Annu Meet Am Meteorol Soc, Phoenix, AZ, Jan. $11-15,2009$

CONAGUA (2011a) Agenda del agua en México. SEMARNAT, Mexico

CONAGUA (2011b) 2030 Water agenda. SEMARNAT, Mexico

Cueto RO, Tejeda A, Jáuregui E (2010) Heat waves and heat days in an arid city in the northwest of México: current trends and climate change scenarios. Int $\mathrm{J}$ Biometeorol 54:335-345

Eakin H, Magaña V, Smith J, Moreno JL, Martínez JM, Landavazo O (2007) A stakeholder driven process to reduce vulnerability to climate change in Hermosillo, Sonora, Mexico. Mitig Adapt Strategies Glob Change 12: 935-955

Ebert E, McBride JL (2000) Verification of precipitation in weather systems: determination of systematic errors. J Hydrol (Amst) 239:179-202

Endfield GH, Fernández-Tejedo I (2006) Decades of drought, years of hunger: archival investigations of multiple year droughts in late colonial Chihuahua. Clim Change 75:391-419

Englehart PJ, Douglas AV (2003) Urbanization and seasonal temperature trends: observational evidence from a datasparse part of North America. Int J Climatol 23: 1253-1263

García, E (2003) Distribución de la precipitación en la República Mexicana. Investigaciones Geográficas, Boletín del Instituto de Geografía 50:67-76. Available at: www. igeograf.unam.mx/web/sigg/publicaciones/publica.php

Garfin G, Crimmins MA, Jacobs KL (2007) Drought, climate variability, and implications, in Arizona water policy, management innovations. In: Colby BG, Jacobs KL (eds) An urbanizing, arid region. Resources for the Future, Washington, DC, p 61-78

Hagemann S, Chen C, Haerter JO, Heinke J, Gerten D, Piani C (2011) Impact of a statistical bias correction on the projected hydrological changes obtained from three GCMs and two hydrology models. J Hydrometeorol 12: 556-578

Hawkins E, Sutton RT (2011) The potential to narrow uncertainty in projections of regional precipitation change. Clim Dyn 37:407-418

- Higgins W, Ahijevych D, Amador J, Barros A and others (2006) The name 2004 field campaign and modeling strategy. Bull Am Meteorol Soc 87:79-94

Ichii K, Kawabata A, Yamaguchi Y (2002) 2002: global corre- 
lation analysis for NDVI and climatic variables and NDVI trends: 1982-1990. Int J Remote Sens 23:3873-3878

IPCC (Intergovernmental Panel on Climate Change) (2007) Climate change 2007: the physical science basis. Contribution of Working Group I to the 4 th assessment report of the Intergovernmental Panel on Climate Change. Cambridge University Press, Cambridge

IRI (International Research Institute for Climate and Society) (2009) CPT tutorial. Available at: http://portal.iri.columbia.edu/portal/server.pt

Karl T, Chang W, Shlesinger M, Knight R, Portman D (1990) A method relating general circulation model simulated climate to the observed local climate. I. Seasonal statistics. J Clim 3:1053-1079

Korecha D, Barnston AG (2007) Predictability of June-September rainfall in Ethiopia. Mon Weather Rev 135: 628-650

Liverman DM (2001) Vulnerability to drought and climate change in Mexico. In: Kasperson JX, Kasperson R (eds) Global environmental risk. UNU and Earthscan, New York, NY, p 201-216

Magaña V (1999) Los impactos de 'El Niño' en México. Centro de Ciencias de la Atmósfera UNAM, Dirección General de Protección Civil, Secretaría de Gobernación

Magaña V, Conde C (2003) Climate variability and climate change and their impacts on the freshwater resources in the border region: a case study for Sonora, México. In: Diaz HF, Morehouse BS (eds) Climate and water-transboundary challenges in the Americas. Kluwer Academic Publishers, Amsterdam, p 373-393

Magaña V, Conde C, Sánchez O, Gay C (1997) Assessment of current and future regional climate scenarios for México. Clim Res 9:107-114

Magaña V, Vázquez JL, Pérez JL, Pérez JV (2003) Impact of El Niño on precipitation in México. Geofis Int 42:313-330

Mearns LO, Gutowski WJ, Jones R, Leung LY, McGinnis S, Nunes AMB, Qian Y (2009) A regional climate change assessment program for North America. EOS 90:311-312

Méndez M, Magaña V (2010) Regional aspects of prolonged meteorological droughts over Mexico. J Clim 23: 1175-1188

Mitchell TD, Carter TR, Jones PD, Hulme M, New M (2004) A comprehensive set of high-resolution grids of monthly climate for Europe and the globe: the observed record (1901-2000) and 16 scenarios (2001-2100). Tyndall Centre Working Paper 55. Available at: www.tyndall.ac.uk

Moron V, Robertson AW, Boer R (2009) Spatial coherence and seasonal predictability of monsoon onset over Indonesia. J Clim 22:840-850

NARCCAP (North American Regional Climate Change Assessment Program) (2009) Available at: www.narccap.ucar.edu

Ojeda-Bustamante W, Sifuentes-Ibarra E, Unland-Weiss H

Editorial responsibility: Mikhail Semenov,

Harpenden, UK
(2006) Integral programming for corn irrigation in northern Sinaloa, Mexico. Agrociencia 40:13-25

Pérez Pérez E, Méndez Pérez JM, Magaña Rueda V (2007) Visualizing future climate in Latin America: results from the application of the Earth Simulator. In: Vergara W (ed) Sustaintable development working papers. Japan Agency for Marine-Earth Science and Technology, World Bank, Washington, DC

Sanchez A (2006) 1944 Water treaty between Mexico and the United States: present situation and future potential. Rev Frontera Norte 18:125-144

Schubert S, Gutzler D, Wang H, Dai A and others (2009) A USCLIVAR project to assess and compare the responses of global climate models to drought-related SST forcing patterns: overview and results. J Clim 22:5251-5272. doi: 10.1175/2009JCLI3060.1

> Seager R, Ting MF, Held IM, Kushnir Y and others (2007) Model projections of an imminent transition to a more arid climate in southwestern North America. Science 316:1181-1184. doi:10.1126/science.1139601

Seager R, Ting MF, Davis M, Cane MA and others (2009) Mexican drought: an observational, modeling and tree ring study of variability and climate change. Atmosfera 22:1-31

SEMARNAT-INE (2006) Tercera Comunicación Nacional ante la Convención Marco de las Naciones Unidas sobre Cambio Climático. Instituto Nacional de Ecología, Secretaría de Medio Ambiente y Recursos Naturales, Mexico

Soule PT, Yin ZH (1995) Short- to long-term trends in hydrologic drought conditions in the contiguous United States. Clim Res 5:149-157

Stern N (2006) Stern review on the economics of climate change (pre-publication edition). Executive summary, HM Treasury, London

Tucker CJ, Pinzon JE, Brown ME, Slayback DA and others (2005) An extended AVHRR 8-km NDVI dataset compatible with MODIS and SPOT vegetation NDVI data. Int J Remote Sens 26:4485-4498

Wilder M, Scott CA, Pineda N, Varady RG, Garfin GM, McEvoy J (2010) Adapting across boundaries: climate change, social learning, and resilience in the United States-Mexico border region. Ann Assoc Am Geogr 100: 917-920

Wilhite DA, Glantz MH (1985) Understanding the drought phenomenon: the role of definitions. Water Int 10: $111-120$

Wilks DS (2006) Statistical methods in the atmospheric sciences, 2nd edn. International geophysics series, Vol 59, Academic Press, New York, NY

Zeng N, Qian HF, Roedenbeck C, Heimann M (2005) Impact of 1998-2002 midlatitude drought and warming on terrestrial ecosystem and the global carbon cycle. Geophys Res Lett 32 doi:10.1029/2005GL024607

Submitted: December 30,2010; Accepted: January 2, 2012 Proofs received from author(s): March 1, 2012 